\title{
PERBEDAAN KECEPATAN ADSORPSI DARAH GOLONGAN O PADA TIGA JENIS MEMBRAN YANG TIDAK DAN DIREHIDRASI SALINE
}

\author{
Harly Prabowo ${ }^{1}$, Harry Laksono ${ }^{1}$, Ratri Maya Sitalaksmi ${ }^{1}$, Viola Stevy Setiyana ${ }^{2}$, Zaravia Dewanty ${ }^{2}$, \\ Nadya Savira Giyansyah ${ }^{2}$. \\ ${ }^{1}$ Staf Pengajar Departemen Prostodonsia Fakultas Kedokteran Gigi Universitas Airlangga, Surabaya \\ ${ }^{2}$ Mahasiswa Program Sarjana Fakultas Kedokteran Gigi Universitas Airlangga , Surabaya \\ E-mail : harly-p@fkg.unair.ac.id
}

\begin{abstract}
Tooth extraction and periodontal disease is the most common cause of alveolar bone resorption. A technique has developed to gain the bone volume back, called Guided Bone Regeneration (GBR). GBR combine the application of bone graft particles and a barrier membrane, to protect bone regeneration from soft tissue invasion that grows faster. Collagen, pericardium, and cortical membranes are resorbable membranes that can be used in the GBR technique. Blood is an essential component of any regeneration that takes place in human body. Before the membrane is applied, it is usually be rehydrated with saline to flex the membrane so that easily applied. To observe the effect of saline rehydration on the $O$ type blood adsoption speed on collagen, pericardium, and cortical membranes. Collagen, pericardium, and cortical membranes each 14 membranes and $2 \times 1.5 \mathrm{~cm}$ in size were divided into two groups, 7 samples for group membranes without saline rehydration and 7 samples for group membranes with saline rehydration. Each group samples were submerged in $75 \mathrm{ml}$ blood. The measurement of the O type blood adsorption speed was examined in 10 minutes for each group. The data was analyzed using Independent T-Test and resulted a significance value of less than 0.05 (Sig<0.05). It shows a significant difference between the control group and the treatment group. There is a difference in the speed of type $O$ blood adsorption between collagen, pericardium, and cortical membranes with and without saline rehydration.Membrane with saline rehydration has a faster blood adsorption speed so that it is less good as a barrier membrane,
\end{abstract}

Keywords: saline, adsorption speed, type O blood, collagen membrane, pericardium membrane, cortical membrane.

\section{PENDAHULUAN}

Masalah kesehatan gigi dan mulut yang paling banyak muncul di masyarakat adalah kehilangan gigi. Hilangnya gigi dapat mengganggu fungsi pengunyahan, bicara, estetik, bahkan hubungan sosial. Salah satu penyebab kehilangan gigi adalah proses ekstraksi gigi. Selain pencabutan gigi, kerusakan tulang alveolar dapat disebabkan oleh penyakit periodontal, gigi trauma, atau resesi. ${ }^{1}$ Pasca ekstraksi gigi terjadi resorbsi tulang alveolar vertikal sebesar $1.5-2 \mathrm{~mm}$ dan horizontal sebesar $40-50 \%$ selama 6 bulan. Apabila kondisi tersebut tidak ditangani resorbsi tulang yang terjadi dapat mencapai $40-60 \%$ secara bertahap dalam kurun waktu 3 tahun. ${ }^{2}$

Perbaikan tulang pasca trauma meliputi fase inflamasi, repair, dan remodeling yang keseluruhannya memegang peranan penting. ${ }^{3}$ Secara keseluruhan, fasefase perbaikan ini dapat berjalan dengan efisien. Namun faktanya, tanpa perawatan lebih lanjut, resorpsi tulang terus terjadi dan tak dapat dihindari sehingga menyebabkan perubahan dimensi tulang secara signifikan. ${ }^{4}$

Defek tulang yang cukup parah atau komplikasi post-traumatic membutuhkan prosedur bone grafting untuk mengisi defek tersebut serta untuk meningkatkan regenerasi tulang. ${ }^{5}$ Guided Bone Regeneration (GBR) merupakan suatu prosedur bedah yang menyertai bone graft dengan memanfaatkan suatu membran barrier. Prosedur ini dapat melindungi jaringan tulang dari jaringan non-osteogenik untuk meningkatkan pembentukan tulang yang lebih lambat dibandingkan dengan jaringan lunak. ${ }^{6}$ Membran barrier terdiri dari dua jenis yaitu membran non-resorbable dan membran resorbable. ${ }^{4}$ Membran barrier resorbable yang dapat digunakan dalam teknik GBR antara lain, membran kolagen, perikardium, dan kortikal.

Membran kolagen umumnya memiliki kekakuan lebih sedikit dibandingkan dengan membran nonresorbable seperti ePTFE atau titanium mesh. Dengan demikian, kemampuan mempertahankan ruang lebih rendah daripada ePTFE atau titanium mesh. Pemakaian Bone graft sering disertai aplikasi membran kolagen selama prosedur GBR. ${ }^{7}$ Membran perikardium memiliki beberapa sifat yang potensial bila digunakan pada GBR diantaranya mudah untuk dijahit, aman, dan relatif murah. Sebuah penelitian yang dilakukan oleh Rothamel (2004) menunjukkan bahwa membran perikardium meningkatkan proliferasi fibroblas pada ligamen periodontal dan osteoblas pada manusia, oleh karena itu, membran perikardium cocok digunakan pada augmentasi defek alveolar ridge bersama dengan material bone graft. ${ }^{8}$ Membran kortikal merupakan membran resorbable dan memiliki beberapa kelebihan, yaitu harga lebih tejangkau, respon jaringan baik, mudah didapatkan, mengandung kolagen tipe I, dan dapat diresorbsi dalam 3-4 minggu sehingga cukup untuk proses regenerasi tulang. ${ }^{9}$

Setelah partikel bone graft diletakkan pada defek, membran barrier yang akan digunakan dipotong dan direhidrasi dengan saline steril agar membran menjadi lembut, lentur, dan fleksibel sehingga mudah 
diaplikasikan dengan mengikuti kontur permukaan dari area defek tersebut. ${ }^{10}$ Untuk memaksimalkan pembentukan tulang, maka dibutuhkan aliran darah untuk menutrisi material bone graft pada area defek. Untuk meletakkan material bone graft maka dilakukan pengeburan tulang kortikal untuk membuka ruang sumsum dan merangsang terjadinya perdarahan pada area tersebut dengan tujuan untuk meningkatkan proses penyembuhan dan pembentukan blood clot serta membuka jalan bagi sel progenitor dan pembuluh darah masuk ke area bone graft. ${ }^{4}$ Penelitian ini menggunakan darah golongan $\mathrm{O}$ karena, menurut penelitian yang telah dilakukan di China golongan darah (ABO tidak mempengaruhi jumlah faktor pembekuan darah. Sehingga tidak berpengaruh terhadap durasi koagulasi darah dan durasi pembentukan bekuan darah, selain itu prevalensi dari berbagai golongan darah menunjukkan persentase golongan darah $\mathrm{O}$ paling sering dijumpai yaitu sebesar $47 \% .^{11,12}$

Pengamatan dilakukan selama 10 menit dengan interval waktu 30 detik. Hal ini didasari oleh tes pembekuan darah dengan cara menempatkan darah pada tabung gelas kemudian menggoyangkan tabung setiap 30 detik hingga terbentuk bekuan darah. Dengan cara ini, waktu pembekuan darah normal adalah 6-10 menit 11. Adsorpsi merupakan peristiwa penyerapan suatu zat pada permukaan zat lain. Adsorpsi dipengaruhi oleh porositas dari suatu adsorben. Adsorben dengan ukuran pori yang besar mempunyai kemampuan menyerap yang lebih tinggi dibandingkan dengan adsorben yang memiliki porositas kecil. ${ }^{13}$ Penelitian ini bertujuan untuk mengetahui perbedaan kecepatan adsorpsi darah golongan $\mathrm{O}$ pada membran kolagen, perikardium, dan kortikal yang direhidrasi dan tanpa rehidrasi saline.

\section{BAHAN DAN METODE}

Penelitian ini telah mendapatkan persetujuan dari komisi etik dengan nomer etik 348/HRECC.FODM/VI/2019. Penelitian ini merupakan penelitian analitik eksperimental dengan menggunakan rancangan post test only group design. Penelitian ini dilakukan di Departemen Prostodonsia Fakultas Kedokteran Gigi Universitas Airlangga.

Sampel yang digunakan adalah membran kolagen, perikardium, dan kortikal masing-masing berjumlah 14 sehingga total sampel yaitu 42 dan berukuran $2 \times 1.5 \mathrm{~cm}$ yang dibagi menjadi dua kelompok , 21 sampel untuk kelompok kontrol (K) membran kolagen, kortikal dan perikardium tanpa rehidrasi saline, dan 21 sampel untuk kelompok perlakuan (P) membran kolagen, kortikal dan perikardium dengan rehidrasi saline dengan waktu yang dilihat pada detik ke 30 hingga ke 600 dengan interval waktu 30 detik. Darah yang digunakan dalam penelitian ini adalah darah golongan $\mathrm{O}$ yang didapatkan dari Palang Merah Indonesia (PMI). Satu kantong darah terkandung $49 \mathrm{ml}$ antikoagulan jenis Citrate Phosphate Dextrose Adenin1 (CPDA-1) agar darah tidak cepat membeku dalam penyimpanannya.

Selanjutnya sampel penelitian direkatkan pada penggaris lalu penggaris direkatkan dengan pipa kaca. Setelah itu pipa kaca tersebut diletakkan pada rangkaian alat penyangga. Kemudian darah golongan O sebanyak $75 \mathrm{ml}$ dimasukkan ke dalam kotak kaca. Rangkaian pipa diturunkan perlahan agar menyentuh darah pada pot kaca dan kamera dinyalakan untuk merekam proses penelitian. Dilakukan pengamatan kecepatan adsorpsi data dengan pengambilan data berupa foto dengan interval 30 detik dengan durasi video 10 menit. Ulangi percobaan tersebut dengan melakukan rehidrasi saline terlebih dahulu. Siapkan $75 \mathrm{ml}$ saline dalam kotak kaca. Rangkaian pipa diturunkan perlahan agar menyentuh saline setelah itu rangkaian pipa dipindahkan dan diturunkan perlahan agar menyentuh darah. Ulangi pengamatan kecepatan adsorpsi darah.

Perbandingan kecepatan adsorpsi darah golongan $\mathrm{O}$ dilakukan pada kelompok kontrol dan kelompok perlakuan. Data yang diperoleh dianalisis dengan uji Komolgorof Smirnov. Data yang berdistribusi normal menggunakan Independent $t$ test, sedangkan data yang berdistribusi tidak normal menggunakan uji Mann Whitney.

\section{HASIL DAN PEMBAHASAN}

Pada penelitian ini sebelum dilakukan uji statistik, terlebih dahulu melakukan uji normalitas dan didapatkan data membran kolagen dan membran perikardium berdistribusi normal sedangkan membran kortikal berdistribusi tidak normal.

Rata-rata kecepatan adsorpsi darah golongan $\mathrm{O}$ pada membran kolagen , perikardium dan kortikal baik yang direhidrasi ataupun tidak dengan cairan saline setiap 30 detik selama 10 menit dapat dilihat pada grafik 1 berikut ini.

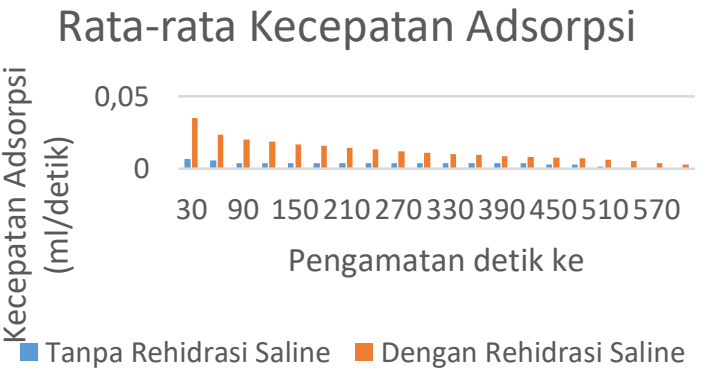

Grafik 1. Grafik nilai rata-rata dari kecepatan adsorpsi darah golongan $\mathrm{O}$ terhadap membran kolagen tanpa rehidrasi saline dan membran kolagen dengan rehidrasi saline.

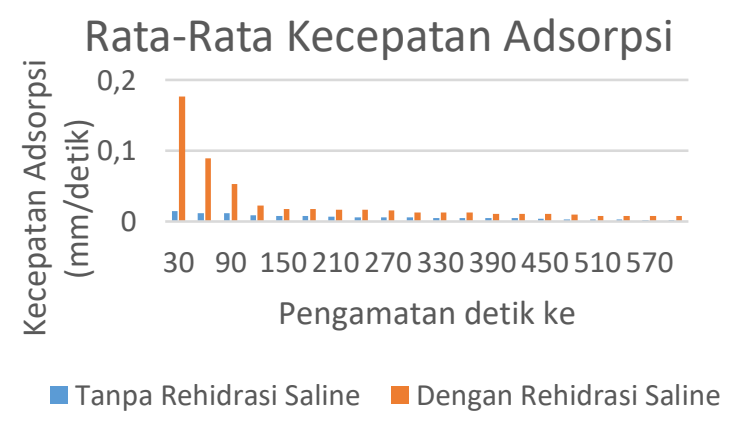

Grafik 2. Grafik nilai rata-rata dari kecepatan adsorpsi darah golongan $\mathrm{O}$ terhadap membran perikardium tanpa rehidrasi saline dan membran perikardium dengan rehidrasi saline. 


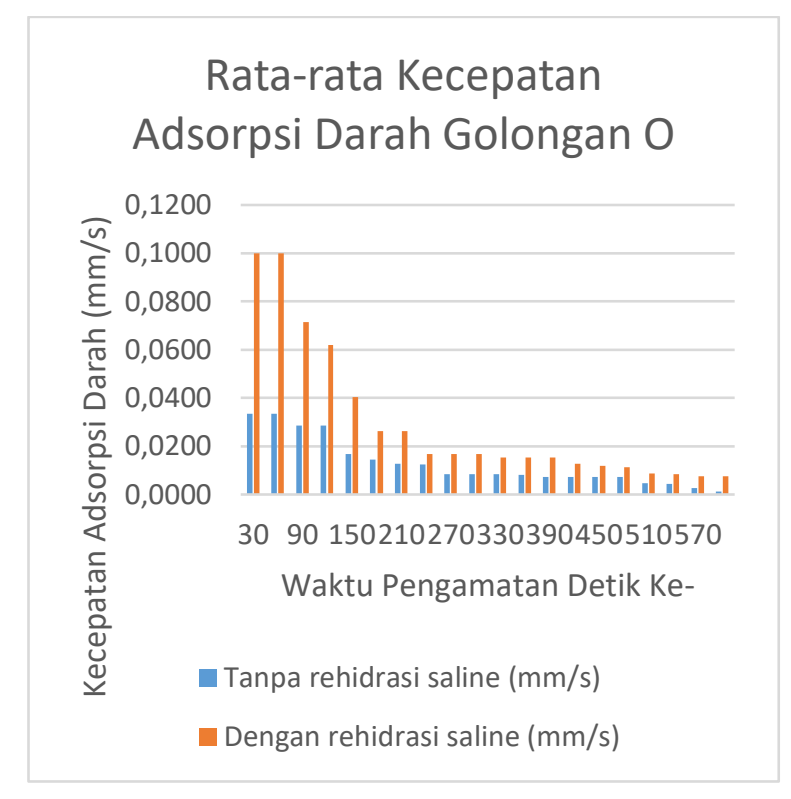

Grafik 3. Grafik nilai rata-rata dari kecepatan adsorpsi darah golongan $\mathrm{O}$ terhadap membran kortikal tanpa rehidrasi saline dan membran kortikal dengan rehidrasi saline.

Pada grafik diatas dapat dilihat nilai rerata kecepatan adsorpsi darah golongan $\mathrm{O}$, tiap 30 detik selama 10 menit. Pada awal penelitian (detik ke 30) terlihat kecepatan rata-rata adsorpsi darah golongan $\mathrm{O}$ yang terbesar pada ketiga membran yang direhidrasi saline. Terdapat kenaikan darah pada ketiga membran yang di rehidrasi saline sedangkan pada ketiga membran yang tidak di rehidrasi saline tidak terlalu nampak kenaikan darah. Kecepatan adsorpsi darah pada ketiga membran dengan rehidrasi saline maupun tidak terbentuk suatu pola yang beraturan relatif stabil semakin menurun selama detik ke 30 hingga detik ke 600.

Uji independent $t$ test dan mann whitney digunakan untuk mengetahui ada atau tidaknya perbedaan kecepatan adsorpsi darah golongan $\mathrm{O}$ ( $\mathrm{mm} /$ detik) pada ketiga membran yang direhidrasi saline dengan ketiga membran tanpa rehidrasi saline. Uji statistik menyatakan terdapat perbedaan yang signifikan terhadap semua kelompok penelitian.

Sebelum diaplikasikan, membran barrier yang akan digunakan direhidrasi terlebih dahulu menggunakan larutan saline steril agar mudah diadaptasi dengan baik pada graft site. ${ }^{14}$ Pada penelitian ini, digunakan saline steril yaitu larutan $\mathrm{NaCl} 0,9 \%$. Menurut Philips dan Gorski (2014), larutan $\mathrm{NaCl}$ 0,9\% merupakan larutan isotonik, yaitu larutan yang memiliki osmolaritas (tingkat kepekatan) yang sama dengan cairan normal tubuh.

Dari penelitian yang telah dilakukan, didapatkan hasil bahwa adsorpsi darah pada membran perikardium yang direhidrasi dengan saline memiliki rata-rata kecepatan yang lebih tinggi dibandingkan dengan kecepatan adsorpsi darah oleh membran yang tidak direhidrasi dengan saline pada setiap pengamatan. Kecepatan terbesar terutama terjadi pada 30 detik pertama, dimana membran perikardium yang tidak direhidrasi dengan saline memiliki rata-rata kecepatan sebesar 0,01446 $\mathrm{mm} /$ detik, sedangkan membran perikardium yang direhidrasi dengan saline memiliki rata-rata kecepatan sebesar $0,06008 \mathrm{~mm} /$ detik. Rata-rata kecepatan adsorpsi darah pada membran kolagen tanpa dan dengan rehidrasi saline terbesar juga terjadi pada detik ke-30, yaitu berturut-turut sebesar 0.006663 $\mathrm{ml} /$ detik dan $0.035200 \mathrm{ml} /$ detik. Sedangkan pada membran kortikal kecepatan adsorpsi darah tanpa dan dengan rehidrasi saline terjadi pada detik ke-60 dan detik ke-30 yaitu sebesar $0,033333 \mathrm{~mm} /$ detik dan 0,1 $\mathrm{mm} /$ detik.

Hal ini sesuai dengan teori yang dikemukakan oleh Phillips dan Gorski (2014) yang menyebutkan bahwa saline merupakan larutan kristaloid. Larutan kristaloid adalah larutan yang ketika dicampurkan dengan larutan lain akan bercampur menjadi satu dan tidak dapat dipisahkan dengan larutan yang dihasilkan 15. Dengan demikian, pada penelitian ini saline akan bercampur dan melarutkan darah sehingga kecepatan adsorpsi darah oleh membran yang direhidrasi dengan saline menjadi lebih tinggi dan memiliki perbedaan yang signifikan dibandingkan dengan membran tanpa rehidrasi saline.

Berdasarkan 20 kali pengamatan yang dilakukan, didapatkan rata-rata kecepatan adsorpsi darah pada ketiga membran yang semakin menurun dari detik ke30 hingga detik ke-600. Hal ini dapat disebabkan karena adanya proses pembekuan darah. Faktor pembekuan darah yang berperan adalah faktor XII. Ketika faktor XII berkontak dengan benda asing, dimana dalam penelitian ini berupa balok kaca, maka faktor XII tersebut akan berubah menjadi enzim proteolitik yang disebut "activated factor XII". Selain itu, platelet yang juga berkontak dengan benda asing akan menghasilkan platelet phospholipid yang mengandung lipoprotein yang disebut dengan platelet factor 3 yang berperan pada proses pembekuan darah. Proses pembekuan darah ini membuat darah berubah dari cair menjadi massa semi-padat yang kemudian memperlambat kecepatan adsorpsi darah oleh membran perikardium ${ }^{11}$.

Apabila darah dikeluarkan dari kantongnya, proses pembekuan akan terjadi dalam waktu 90-150 detik pada udara terbuka ${ }^{16,17}$. Oleh karena itu, setelah 30 detik pertama kecepatan adsorpsi darah akan semakin menurun seiring dengan bertambahnya waktu pengamatan.

Berdasarkan hasil uji independent $t$ test pada ketiga membran, didapatkan $\mathrm{p}<0.05$ pada detik ke-30 hingga detik ke-600 yang berarti terdapat perbedaan yang signifikan antar kelompok perlakuan. Dari hasil uji tersebut didapatkan sesuai hipotesis yaitu kecepatan adsorpsi darah golongan $\mathrm{O}$ (ml/detik) pada membran yang direhidrasi saline dengan membrane tanpa rehidrasi saline menunjukan adanya perbedaan yang signifikan antar kelompok perlakuan karena saline dapat melarutkan darah sehingga lebih cepat mengalami adsorpsi ${ }^{15}$.

Membran yang telah direhidrasi saline memiliki kecepatan adsorpsi darah lebih cepat sehingga kurang baik sebagai membran barrier karena darah dapat memberi nutrisi pada jaringan lunak sehingga jaringan lunak tumbuh lebih cepat dan melekat pada ruang yang seharusnya untuk pertumbuhan tulang ${ }^{18}$. 


\section{KESIMPULAN}

Dari hasil penelitian yang telah dilakukan dapat disimpulkan bahwa adsorpsi darah golongan $\mathrm{O}$ pada membran kolagen, pericardium dan kortikal yang direhidrasi saline lebih cepat dibandingkan yang tanpa rehidrasi saline.

\section{UCAPAN TERIMA KASIH}

Penulis mengucapkan terima kasih kepada Tuhan Yang Maha Esa, keluarga penulis dan semua pihak yang telah membantu dalam penyelesaian artikel ini.

\section{DAFTAR PUSTAKA}

1. Amrullah SSA, Sani R, Arifin N, Ruslin M. Augmentasi Tulang Alveolar eengan Osteogenesis Distraksi. Dentofasial. 2012;11(3): 174-179.

2. Sheikh Z, Sima C, Glogauer M. Bone replacement materials and techniques used for achieving vertical alveolar bone augmentation. Materials (Basel). 2015;8(6): 2953-2993. doi: 10.3390/ma8062953

3. Stok J Van Der. Bone Graft Substitutes Developed for Trauma and Orthopaedic Surgery. Ned Tijdschr Traumachir. 2015;23(4): 6169. doi:https://doi.org/10.1007/s12506-015-0024-y

4. Liu J, Kerns DG. Mechanisms of Guided Bone Regeneration: A Review. Open Dent J. 2014;8: 5665. doi:10.2174/1874210601408010056

5. Kumar P, Vinitha B, Fathima G. Bone grafts in dentistry. Bone Graft Dent. 2013;5(1): 125-128. doi:10.4103/0975-7406.113312

6. Rozalia D, George I. M, Giorgio M. C, Peter V. G. The role of barrier membranes for guided bone regeneration and restoration of large bone defects: Current experimental and clinical evidence. $B M C$ Med. 2012;10. http://www.biomedcentral.com

7. Lee SW, Kim SG. Membranes for the Guided Bone Regeneration. Maxillofac Plast Reconstr Surg. 2014;36(6): 239-246. doi:http://dx.doi.org/10.14402/jkamprs.2014.36.6. 239

8. Hitti RA, Kerns DG. Guided Bone Regeneration in the Oral Cavity: A Review. Open Pathol J. 2011;5(1): 33-45.

9. Kamadjaja DB, Harijadi A, Soesilawati P, et al. Demineralized Freeze-Dried Bovine Cortical Bone: Its Potential for Guided Bone Regeneration Membrane. Int J Dent. 2017; 2017.
10. Wessing B, Urban I, Montero E, et al. A Multicenter Randomized Controlled Clinical Trial Using A New Resorbable Non-cross-linked Collagen Membrane For Guided Bone Regeneration At Dehisced Single Implant Sites: Interim Results Of A Bone Augmentation Procedure. Clin Oral Implants Res. 2016: 1-9. doi:10.1111/clr.12995

11. Widjajakusumah, M dan Tanzil, Antonia, (Ed). Guyton Dan Hall Buku Ajar Fisiologi Kedokteran. 12th ed. Elsevier (Siangapore) Pte Ltd; 2016.

12. Wang Z, Dou M, Du X, Ma L, Sun P, Cao H, Ye $\mathrm{S}$, Jiang $\mathrm{P}$, Liu F, Lin F, Zhang F, Li C. Influences of ABO Blood Group, Age, and Gender on Plasma Coagulation Factor VIII, Fibrinogen, Von Willebrand Factor and ADAMTS13 Levels in A Chineese Population. Peer J. 2017;5: e3156. doi:10.7717/peerj.3156

13. Syauqiah I, Amalia M, Kartini HA. Analisis Variasi Waktu Dan Kecepatan Pengaduk Pada Proses Adsorpsi Limbah Logam Berat Dengan Arang Aktif. Info Tek. 2011;12(1): 11-20.

14. Urban I, Lozada J, Wessing B, Suárez-López del Amo F, Wang H-L. Vertical Bone Grafting and Periosteal Vertical Mattress Suture for the Fixation of Resorbable Membranes and Stabilization of Particulate Grafts in Horizontal Guided Bone Regeneration to Achieve More Predictable Results: A Technical Report. Int J Periodontics Restorative Dent. 2016;36(2): 153-159. doi:10.11607/prd.2627

15. Phillips LD, Gorski L. Manual of IV Therapeutics: Evidence-Based Practice for Infusion Therapy.; 2014.

16. Thiruvenkatarajan V, Pruett A, A. Das S. Coagulation testing in the perioperative period. Indian $J$ Anaesth. 2014;58(5): 565-572. doi:10.4103/0019-5049.144657

17. Soekobagiono, Prabowo H, Christopher D. Perbedaan kecepatan adsorbsi darah golongan $\mathrm{O}$ pada hidroksiapatit ukuran 150 - $355 \mu \mathrm{m}$ yang tidak disterilkan dan yang disterilkan dengan pemanasan kering ( The Difference of Blood 's Adsorption Rate ( Type O ) by Hydroxyapatite with the size of $150-35$. J Prosthodont. 2017;8(1): 1, 6.

18. Emam HA, Stevens MR. Concepts in Bone Reconstruction for Implant Rehabilitation. $A d v$ Oral Maxillofac Surg. 2013;23: 617-640. 